\title{
The Islamic Drug Prevention Method among Thai Muslim Youths in Ban Don Khilek, Phawong Sub-District, Muang District, Songkhla Province
}

\author{
Rutchadee Binwang ${ }^{1} \&$ Kasetchai Laeheem ${ }^{1}$ \\ ${ }^{1}$ Faculty of Liberal Arts, Prince of Songkla University, Hatyai, Thailand \\ Correspondence: Kasetchai Laeheem, Faculty of Liberal Arts, Prince of Songkla University, Hatyai 90110, \\ Songkhla, Thailand. E-mail: Lkasetchai@yahoo.com
}

Received: September 8, 2013

Accepted: September 16, 2013 Online Published: November 29, 2013

doi:10.5539/ass.v9n17p283

URL: http://dx.doi.org/10.5539/ass.v9n17p283

\begin{abstract}
This study aimed to investigate a method and effects of community participation in an Islamic drug prevention method among Thai Muslim youths in Ban Don Khilek, Tambon Phawong, Muang District, Songkhla Province. The data were collected through in-depth interviews, group discussions, and practice with four groups of key informants, namely, 20 Muslim youths, 10 parents and guardians, 8 religious leaders, and 3 local leaders. Descriptive content analysis was conducted using comparative logic of concepts, theories, research reports, and context.

The findings revealed that a suitable Islamic way of drug prevention method was the establishment of a group called "Creative Youth Group of Ban Don Khilek" with religious leaders, and local leaders as consultants and supporters. The main role of the youth group was organizing creative activities for learning which were learning activities on Islam and the way of living, group discussions, moral and ethical camp for youths, training for parents and guardians, and information broadcasting activities. The study was financially supported by the Institute of Southern Health Research and Development, Prince of Songkla University. The activities emphasized on participation from all parties and continuity of the activities. It was found that the process of organizing activities could develop youths' potential in various aspects. Moreover, the target group acquired knowledge, learned facts about harms of drug addiction, and practiced living according to the Islamic way that eventually led them far away from drugs.
\end{abstract}

Keywords: prevention method, drug problems, Thai Muslim youths, Islamic way, creative youth group

\section{Introduction}

Narcotic drugs have severe effects on users, their families, communities, societies, state management, economics and financial condition of the country. In addition, drugs threaten, undermine and destroy the country and affect its security and reputation as Prayatsap (2011) states that all types of narcotic drugs whether they are depressants, stimulants, or hallucinogens, are harmful to users and users may become criminals without realizing it. Drug users cannot stop using them but rather increase the amount they use until their bodies deteriorate and die gradually.

Furthermore, using and being involved with narcotic drugs are taboos according to Islamic law in which punishments are clearly specified. Boonchom (2010) states that for people who are involved with drugs, punishments according to Islamic law are justice and there are different levels of severity such as detainment, whipping, or warning, etc., and for whipping as punishment, at least forty lashes are given. For punishment in the next world, it depends on Allah's command. Office of the Thai Muslim Press (n. d.) reported punishments according to Islamic law for people who are involved with alcoholic drinks "Whoever sips or drink even only one gulp of alcoholic drink, Allah will not accept his prayers for three days. Whoever drinks a glass of alcoholic drink, Allah will not accept his prayers for 40 days; and whoever is an alcoholic, he must drink blood and pus of devils".

Nowadays, the problem of drug addiction in youths is a very worrying problem because statistically the number of youths who are addicted to drugs is higher than any other age groups. According to the statistics of drug-addicted patients in Songkhla province, there were 6,683 drug related arrests, most drug addicts are in the 
age range of 14-19 years old, and most of them are school students or students in higher educational institutions (Songkhla Tanyarak Hospital, 2011). In Thailand, there were 320,972 drug related arrests in 2012, 75.8 percent of these were Thais convicted for yaba (common names for methamphetamine) related offenses. Estimates suggest that at least 15\% of the population in Thailand uses Yaba (Mordey, 2012; Office of the Narcotics Control Board, 2013). A primary survey on drug addiction among youths of Ban Don Khilek community shows that it is a very worrying problem, too. Most youths use drugs that are easily found in the area such as mitragynine water, marijuana, ice (methamphetamine), and amphetamine, etc. An important cause of the problem is families do not use Islamic principles in their living and training their children. Other causes include availability of drugs in the community, and peers' persuasion while most youths lack knowledge and understanding about dangers of drugs.

Causes of drug addiction are multiple and are related to the individual, but also to the family and friends environment. Parents and friends did not live up to follow Islamic principles is the major risk factor for drug addiction. This is in line with Anmunajid (2004), and Mahama (2009) who claimed that drug addiction of Thai Muslim youth is a major risk problem in Muslim society; because today, conventional Muslim society, which used to be strictly based on Islamic teaching, has disappeared. What is left are simply beliefs and religious rites which are merely imitations of the previous generation. Laeheem and Baka (2010), and Laeheem (2012) found that Thai Muslim youth from families where parents did not live up to the expectations of Muslim society, nor did they follow Islamic principles can affect and is the highest risk factor for the drug addiction.

Some related organizations have done something about solving the problem of drugs in Ban Don Khilek but they cannot solve it because they lack community participation. Most organizations solve the problem with emphasis on responding to policy of their respective organizations, and thus, there are conditions and limitations regarding time in their work focusing on success in terms of quantity. They use the problem solving process that involves arresting, fining, and detaining people who are involved with drugs. This process or the methods lack participation of people in the area. Moreover, righteousness can be bought with power, and money. As a result, the problem of drugs has not been solved but dangers of drugs have been more extensive and more difficult to control and to solve.

Therefore, if Ban Don Khilek community does not have cooperation in solving drug problems among youths, the problems will affect the future of the youths resulting in a lack of opportunities in social and occupational aspects as well as in credibility. The community cannot be developed because manpower is weak and unqualified resulting in the country's being underdeveloped, weak, and backward. Thus, it is very necessary to accelerate participatory action research in which people in the community participate in determining the model for prevention of drug problems among Thai Muslim youths of Don Khilek community that is suitable for the area context and the target group in the community. As a result, it can be expanded to Muslim communities in other areas, especially in the three southern border provinces.

\section{Research Objectives}

1) To study a method for prevention of drug problems according to the Islamic way among youths in Band Don Khilek Community, Tambon Phawong, Mueang District, Songkhla Province.

2) To study the results of using the method for prevention of drug problems according to the Islamic way among youths in Band Don Khilek Community, Tambon Phawong, Mueang District, Songkhla Province.

\section{Methods}

\subsection{Key Informants and Data Collection Methods}

This study is a participatory action research consisting of two phases: Phase 1: People in the community jointly determine the method in preventing drug problems according to the Islamic way that is suitable for the area context and the target group, and experiment the method with the target group in the community. Phase 2: following up and evaluating the results of the experiment on drug prevention method according to the Islamic way. The data were collected through in-depth interviews, group discussions, and actual practice with four groups of key informants, namely, 20 Muslim youths, 10 parents and guardians, 8 religious leaders, and 3 local leaders. The procedure was as follows:

Stage 1: Designing and planning stage-a discussion meeting was held attended by 41 participants consisting of youths, parents and guardians, religious leaders, and local leaders. The purpose of the meeting was to jointly design activities and plan operations in drug prevention holding on to principles of socialization the Islamic way that was suitable for the area context and characteristics of the target group in the community.

Stage 2: Operation stage-At this stage, an operation resulted from Stage 1 was conducted, and the four groups of key informants: youths, parents and guardians, religious leaders, and local leaders participated in the drug 
prevention operation for 8 months from December 1, 2012 to July 31, 2013.

Stage 3: Follow-up and evaluation stage-A discussion meeting was held in order to reflect the results, and conduct in-dept interviews with the target groups which were a group of 20 youth, a group of 10 parents and guardians, a group of 8 religious leaders, and a group of 3 local leaders.

\subsection{Data Analysis}

The data from the in-depth interviews, group discussions, and the actual practice were processed and analyzed by reviewing the data several times. Then comparisons were carried out using comparative logic with concepts, theories, and research and contexts. The contents were then analyzed to identify main issues or analytical statements that specified the prevention method and solutions to drug problems according to the Islamic way, and the results of the experiment. Finally, the issues obtained were written in extensive descriptions to explain the phenomenon that was studied covering all the issues that had been designated.

\section{Results and Discussion}

From the discussion meeting to brainstorm the methods of drug prevention according to the Islamic way for youths in Ban Don Khilek, it was found that the suitable way that was in correspondence with the area context of Ban Don Khilek was an establishment of the group called "Creative Youth Group of Ban Don Khilek". Consequently, the creative youth group of Ban Don Khilek was established and in operation to organize many different activities to manage the learning process of drug prevention for youths in the community. The learning activities were based on the learning process of Islam. There were 35 members in the age range between 8 and 24 years old; there were 10 adults acting as advisors consisting of religious leaders, and community leaders (village headmen). At the beginning, the group received a budget of 70,000 baht for conducting a research project from the Institute of Research and Development for Health of Southern, Thailand of Prince of Songkla University. Youths have been regarded as the main group that drives the learning process management for drug prevention according to the Islamic way. There are five main activities, each of which has the following important elements and outcomes:

\subsection{Reading to Learn about Islam}

This is a creative activity for learning the way of life according to Islamic principles. The activity is organized using the time between the Maghrib (Note 1) praying time (sunset) to the Isha (Note 2) praying time (evening) for youths in the community to practice reading the Koran at homes of teachers who volunteer to teach children so that they learn about Islam at the same time as practice to read the Koran. In this activity, the reading materials are those that present the content of living correctly according to the Islamic way from Allah's commands and Muhammad the prophet's teaching; and along with these are contents about dangers and bad effects of drugs, and contents that are useful for people who are co-learners of Islam. Thus, youths learn the contents and understand about the harms of drugs. They also exchange their knowledge and experience so that they all learn from each other. They take turns reading and practice drawing conclusions from the reading.

From the reading activity to learn about Islam, it was found that the youths who participated in practice the reading skill to learn about Islam learned the contents that were read to them about the harms and bad effects of drugs, and about living the Islamic way. They have conversations to exchange knowledge and experience about the contents that the reader presents to them. There are mentors to link the contents of what the youths exchange among themselves with Islamic teachings. From interviewing parents of the youths who participated in the activity, it was found that the children often took what they learn from doing the activity home and to tell or suggest their parents.

The results of the study revealed that the youths who participated in the activity, reading to learn about Islam, understood the living principles according to the Islamic way, and Islamic punishments for drug addicts. Thus, this activity is deemed a base for instilling important elements in living in youths so that they can live better in the present society. It also instills thoughts, attitudes, and views that are useful and can be used in preventing and solving drug problems in youths in a suitable and good way for the community. This is in accordance with Laeheem and Baka's statements that most Thai Muslim youths have their way of living that are in contrast with the Islamic principles and are not in line with expectations of Muslim society and are not according to social norms, and lead them to drug use. Thepsitha (1998) said that the knowledge level of religion and the level of participation in religious activities are considered important factors that influence youths' behaviors. Youths who have knowledge about the religion at a high level and who participate in religious activities usually have a high level of desired behaviors that are in accordance with the social norm. 


\subsection{Group Discussion Activity}

This activity is for members of the creative youths group of Tambon Ban Don Khilek to talk about harms and bad effects of drugs. They discuss to find ways for drug prevention in the risk group, to discuss about the Islamic principles for living; they continue to discuss these matters every day. They also bring articles or periodicals about dangers of drugs, books about the value of doing good deeds, commands from the Koran, and data and information about the drug situation in the community to discuss and exchange ideas and opinions, and find channels for disseminating the knowledge to their community. Members are assigned to search information about harms and effects of drugs, and a perfect Muslim way of life, to propose issues for discussions and consultations.

The results of the group discussion activity revealed that youths who participate in the discussions and practice speaking and exchanging knowledge and ideas about the dangers of drugs understand the perfect Muslim way of life, understand about the drug situation in the community, and are ready to consult or discuss to help find ways to manage the drug problems. It is observable that at the beginning of the discussion activity, participants were reluctant to speak but aster the activity continued for three months, it was found that the youths spoke more, and learned how to act or behave correctly according to the Islamic principles in the present society. They could link Islamic principles with the living principles in the present society. Among the youths who participated in the activity, it was found that they realized more about the harms of drugs and use the knowledge they received from participating in group discussions to give advice to their friends who had risk behavior about drugs. Moreover, they understand the way of life according to the Islamic principles and are ready to behave accordingly, correctly, suitably, and in line with expectations of the community. They learn and develop their potential in becoming group discussion leaders, a role for which they take turns to be responsible. Furthermore, together, they realize the importance of prevention and solution to drug problems and this has led them to organize activities to develop their community and people's potential. Some of the activities are: establishing youth groups so that youths can earn extra income, for example, from making leather hand bags, growing plants and trees along the roads and in the cemetery (Kubor), training in the central Malayu language and/or dialects, holding summer camps, etc. These activities are found to increase the number of members of the group discussion activities.

From the results mentioned above, it can be seen that the group discussion activity influences youths to learn the contents about the harms and dangers of drugs on themselved, their community and society, in addition to learning about the Islamic way of life that is a starting point for youth potentiality development. As a result, youths have opportunities to exchange their ideas and experiences, and consult each other about how to develop their community through different activities. This process is considered an opening of a space and a beginning of acceptance for youths' potential that has become an important channel for drug prevention among youths who do group activities. The reason is because the group discussion activities focus on learning together the dimension of how to live correctly according to the religious principles, and the dimension of dangers of drugs and bad effects for drug use. The group discussion activities are based on potential development for group members who also receive continual advice and support from community leaders. Munjit, Tongthip, Jaipang, Pummaichaiyapreuk, Putthawong, and Ruensit (2007) found that drug problems in villages decreased considerably as a result of community participation and continuation of group discussion activities for controlling narcotic substance prevalence in the community. They found that important factors in every process were community participation, and continuation of activity operation for sustainable and efficient control for narcotic drugs and drug prevalence in the community. Laeheem (2013a) states that ways to solve problems of behaviors problems among students or youths were: group study activities emphasizing training on correct Islamic ways, giving advice, instructive reprimands, providing good models, and teaching religion, discipline training, and organizing special projects emphasizing the socialization process of their mind, emotion, intelligence, and Islamic religious spirit. Laeheem (2013b) found that students or youths who participated in group study activities and those participated in school religious activities were not different in their behaviors problems. The students or youths participating in group study activities had statistically less behaviors problems than those participating in Islamic religious activities.

\subsection{Summer Training Camp Activity}

The training provides knowledge about drugs, and practice in living the Islamic way, and it was attended by a group of 80 youths in the community covering four sub-communities in Ban Don Khilek area. Members of the Creative Youth Group of Ban Don Khilek were mentors while 50 leaders and people in the community acted as a directing group and provided support in different aspects of the camp activities. The summer training camp activity was held at the Child Development Center of Ban Don Khilek Community Masjid for seven days from April 12 to 18, 2013 (during Songkran festival). The activity was cooperation between the Creative Youth Group 
of Ban Don Khilek and people in the community who participated in every stage from brainstorming, fund raising, and participating in the activity. On the last night of the camp activity, there were shows performed by youths to show their talents, and there was a sermon for parents and guardians about raising children the Islamic way so that they are safe from drugs.

The study found that the youths in the community who participated in the process practiced the skills of living the Islamic way from when they woke up to when they went to bed. They received information and knowledge about dangers of drugs that could affect their health, family, community, and society. Moreover, they learned about self-care, consuming healthy food, and exercising. For youths from the Creative Youth Group of Ban Don Khilek who were the main drivers and mentors for children to participated in the camp had the opportunity to practice working together, and managing the learning process of living the Islamic way while giving information and knowledge about dangers of drugs to children who participated in the camp. For community leaders and parents or guardians who participated in the activity, they were ready to help the youths who ran the camp, and they witnessed the training process of the youth camp activity at the same time. Thus, they could perceive how the youth training the Islamic way could save their children from dangers of drugs that are problems in the community.

The study results mentioned above indicate that organizing summer ethic and moral camps is one activity that can prevent and solve drug problems. The camp focuses on learning how to live correctly according to the Islamic way. They are taught in a creative way, and mentors in the camp behave as good role models for youths who participated in the camp. Above all, there are religious teaching and disciplinary training all along the camp activities that is a way for youth development in order to distance them from narcotic drugs. This is in congruence with the guidelines for prevention and solution of misbehaviors in youths suggested by the Committee of Education, Religion, Art and Culture (2003) that youths should be taught correctly and creatively; there should be good role models for them; and religion should be taught in addition to disciplinary training. Hence, the ethic and moral camp is considered a youth training activity where youths who are mentors are also trained to practice according to the Islamic principles. Youths learn about harms and bad effects of drugs through creative activities that lead to skill development in behaving according to expectations of their religion, community, and society. These are important foundations for them to live amidst social environments full of vices and problems, especially drug problems. Youths are taught and given understanding about harms and dangers of drugs so that they distance themselves from the vicious cycle of drug use and drug-related behaviors. For the youths from the Creative Youth Group of Ban Don Khilek who were mentors in the learning and training management of the camp, they had opportunities to acquire various skills and came to realize the importance of living the Islamic way, and dangers of drugs. Thus, the Creative Youth Group of Ban Don Khilek was recognized as its members were ready to live their lives the way expected by their community.

\subsection{Training to Provide Knowledge for Parents and Guardians}

The training for parents and guardians in caring for youths the Islamic way and psychology in training youths to distance themselves from drugs was organized on April 24, 2013 at the Child Development Center of Ban Don Khilek Community Masjid, and it was participated by 30 parents and guardians. The speakers were experts in caring for youths the Islamic way and psychology in training youths to distance themselves from drugs. The speakers not only gave lectures but also reflections on problems in caring for youths nowadays.

The results of the training for parents and guardians revealed that they learned techniques in youth training the Islamic way and psychology for youth training so that they distance themselves from drugs, and they were ready to adapt them in raising their children. Most of the parents and guardians reflected that in the past they always put the blame on their children and overlooked details that could cause negative feelings in various ways such as they never thanked when their children did something properly, and never apologized when they did something improperly to their children. Some of them admired other children in front of their own children which could hurt their children's feelings. All of these are considered ways that could be used in training youths in order to distance them from unsuitable behavior, especially behavior related to narcotic substance.

Thus, training parents and guardians is to give importance to the institution of family allowing it to take part in the drug prevention process because family is an important starting point causing youths to be involved with narcotic substances. Furthermore, people close to youths must pay close attention to them, care for them, love them, and be the persons who youths can turn to for help and support when they have problems. As stated by Office of Public Relations, Khon Kaen (2013), parents and guardians must pay close attention, care for, and love their children and give them help and support when they have problem so that they can consult and ask for help in solving the problems. In addition, parents and guardians should use reason rather than emotion with children 
because using emotion can hurt their feeling and chase them away from home or turn to drugs that finally ruin their future. Drug-related problems among most youths start from family such as a broken home, quarrelling parents, unsuitable methods of raising, lack of understanding, lack of trust, and lack of good consultation for problem solving from family lead to negative attitudes and viewpoints towards family. Consequently, the last resort for youths is a group of peers that they trust. So, they spend most of their free time with this peer group, and this lead them to unsuitable behavior. Therefore, organizing a learning process of psychology in raising youths according to the Islamic way for parents and guardians is deemed a significant starting point for drug prevention in the community with family as a good starting point.

\subsection{Information Broadcasting with Loudspeakers}

This is a method of presenting information on harms and bad effects of drugs through loudspeakers in the community by members of the Creative Youth Group of Ban Don Khilek who search information about dangers of drugs, and the way of life according to Islamic principles. The broadcasting has been supported by the village headmen of Ban Don Khilek Community, and good advice about public relations has been provided by people in the Ban Don Khilek Community.

From the three-month public relations, it was found that people in the community including children, youths, and the general public have received knowledge and understanding about harms of drugs that can affect physical and mental health of people in the family, community, and society. As a result, people in the community who smoke have come to realize the bad effects of smoking and will gradually reduce the number of cigarettes they smoke to eventually stop smoking. For youths whose behavior is related to other narcotic substances such as cigarette, mitragynine water, marijuana, and amphetamine, it was found that they had reduced their use, and talk among themselves about bad effects of drugs, and this had changed their viewpoints and thought that they had had that drugs could not harm them because they were healthy and strong. It was also found that more youths have become interested in playing sports, such as playing Takraw and football in the late afternoon. This is because they have heard from the broadcasting that invites youths to exercise for health, and raise the awareness and belief that doing exercise can expel poisons from drugs that has accumulated in their body, and make them physically healthy. Furthermore, public relations is a way to practice and develop speaking skills for youths, and gives them confidence in expressing themselves. The parents are proud of their children who can speak to present useful information to people in their community. As a result, more people see the importance of the Creative Youth Group of Ban Don Khilek, and continuously bring their children to participate in the activity.

As can be seen, public relations through broadcasting with loudspeakers are broadcasting about dangers of drugs and punishment according to the principles of Islam and law, the Islamic way of living, and techniques in youth training. This broadcasting has resulted in youths' realization of harms and bad effects of drugs that can change youths' behavior and distance them from narcotic drugs. This is supported by Office of Public Relations, Khon Kaen (2013)'s statement that for drug prevention to be effective for a long term and to be sustainable, education and knowledge about harms and bad effects of drugs should be provided continually for the general public, teachers, parents, guardians, youths and children. In addition to this, this method is a way to give viewpoints and thinking methods to youths so that they are empowered with their own faith and ability, see their own value and importance for themselves and people in the community. This is an important concept that can inspire youths to develop themselves continually to prevent behavior related to drugs. Prayatsap (2011) states that good Muslim youths will be important power in developing Muslim society so that it is stable, secure, and outstanding in the world society that is a channel leading youths to behavior that is far away from vices and evils including narcotic drugs.

\section{Conclusions and Recommendations}

The method for drug prevention according to the Islamic way among youths in Ban Don Khilek Community, Tambon Phawong, Muang District, Songkhla Province is the establishment of "the Creative Youth Group of Ban Don Khilek". The group has 35 members, and 10 adults consisting of religious leaders, and community leaders (village headmen) as advisors. The main role of the group is to drive the learning process of drug prevention according to the Islamic way through doing creative activities. The activities include learning activities about the Islamic way of living, group discussion activities, children camps, training activities for parents and guardians, and information broadcasting. The group has received a budget for operation of 70,000 baht from a research project from the Institute of Research and Development for Health of Southern Thailand of Prince of Songkla University. The group has provided information about dangers of narcotic drugs and their bad effects at the same time as instilled Islamic ethics in the youths because religion is a social unit that provides socialization and is the main principle to which people hold on. Moreover, it is the frame for people to hold on to in doing good deeds, 
having moral and ethics, the feeling of right and wrong, behaving suitably, and do religious activities designated by the religion. Thepsitha (1998) describes religion as a factor that makes people good with moral, ethics, and feeling of good and bad, and religion is an important outlet for drug problems in the community. Kula (2009) states that the way or process in managing drug problems in the Muslim community must hold on to the Islamic principles as the frame of thought for the work management process. The target group should be given opportunities, support, and methods to understand the problems and effects of drug use so that they can improve and change themselves. Laeheem (2012) specifies that community leaders should realize the importance of youth problems, and should establish a "Village Youth Club" that develops youths' potential so that youths can become leaders of changes and are able to solve community problems.

The results of doing creative activities for learning to prevent drug problem according to the Islamic way among youths in Ban Don Khilek community revealed that the operation process could develop youths' potential in many aspects through doing creative learning activities. Consequently, youths can distance themselves from narcotic substances, acquire knowledge, know facts about dangers of drugs, realize the facts and can distance themselves from drugs. At the same time, they learn and practice living the Islamic way through creative learning activities that are operated by the Creative Youth Group of Ban Don Khilek. The activities include psychology in training youths the Islamic way, and Islam and living in the family. It is necessary that the learning process is based on participation from all parties with continuity, and to be sustainable because participating voluntarily can result in enthusiasm and true intention in order to achieve the goal that has been set. According to Keawhawong (1999), Patanapongsa (2004), and Bureekul (2005), participation is to provide opportunities for individuals to join in thinking, searching the problem and its causes. Participation in planning the activities, participation in doing the work, and participation in follow-ups and evaluation freely and equally from the beginning to the end of the operation are participation that is voluntary, determined, sincere, enthusiastic to achieve the goal. For the first step, there is a gathering of community leaders, parents and guardians, and youths in the community in order to brainstorm for searching ways to solve drug problems in the community according to the Islamic way for sustainable problem solving. This is in line with Laeheem (2012) who states that the way to care for youths according to the Islamic way is to involve all related organizations and individuals to cooperate in integrated operation and provide opportunities for youths to participate in all the operation of every process. Laeheem (2013c) found that the Islamic way of youth care should be conducted with cooperation from all organizations and people who are concerned; youth should be given opportunities to participate in every step of the process; Muslim leaders should be encouraged to realize the importance of their roles and responsibilities for youth care; and a "Village Youth Club" should be established by using local a masjid as the center of operation. The club should have an administrative structure, concrete roles and responsibilities, and activities both in the religious and the social sectors that correspond with needs of the Muslim youth and are in line with Islamic principles.

Thus, the main principle for solving drug problems among Muslim youths is to establish a group, club, or a social organization to drive the work by integrating religious principles in solving drug problems in the community. A space should be open for youths in the community to play a major role in operations under support, promotion, and advice from leaders, knowledgeable people, and other people in the community. It is very necessary that studies be conducted on ways to open a creative learning space in the community for youths whose behavior is related to narcotic substances to provide them with opportunities to develop their potential that lead to behavioral change and to solution of drug problems in the community and society.

\section{Acknowledgements}

We are grateful to the Research Fund, Faculty of Liberal Arts, Prince of Songkla University for support this project.

\section{References}

Anmunajid, S. (2004). Prohibited relationship. Retrieved February 19, 2010, from http:/www.majlis-ilmi.org/islam/modules.php?op=modload\&name=Sections\&file=index\&req=viewarticle \&artid $=1$ \&page $=1$

Boonchom, A. (2010). Principles of drug types. Retrieved June 24, 2012, from $\mathrm{http}: / / \mathrm{www}$. sunnahstudent.com/forum/index.php?topic $=4253.0$

Bureekul, T. (2005). Participation theories and processes. Nonthaburi: King Prajadhipok's Institute.

Committee of Education, Religion, Art and Culture. (2003). Report summarizes the problems of the students' controversy and violence. Bangkok: the Senate. 
Kaewhawong, T. (1999). The strengthening process of strong communities. Khon Kaen: Klangnanawittaya.

Kula, R. (2009). Masjid and solving of drug problems. Retrieved January 20, 2013, from http://www.learners.in.th/blogs/posts/423077

Laeheem, K. (2013a). Guidelines for solving Bullying behaviors among Islamic private school students in Songkhla province. Asian Social Sciences, 9(11), 83-89.

Laeheem, K. (2013b). The effects of group study activities on the reduction of bullying behaviors among Islamic private school students in Songkhla province. Asian Social Sciences, 9(11), 308-315.

Laeheem, K. (2013c). The Islamic way of youth care by Muslim leaders in the three southern-border provinces of Thailand. Asian Social Sciences, 9(10), 160-168.

Laeheem, K., \& Baka, D. (2010). A study of the Thai Muslim youth's way of life to maintaining peace in the three southern border provinces of Thailand. Songklanakarin Journal of Social Sciences \& Humanities, 16(6), 973-988.

Laeheem. (2012). Youth supervision based on the Islamic beliefs of Muslim leaders in three southern province communities. Kasetsart Journal: Socail Sciences, 33(3), 454-463.

Mahama, M. (2009). Islam: Way of life. Songkhla: Po-bard.

Mordey, A. (2012). Drug use in Thailand. Retrieved September 13, 2013, from http://www.thecabinchiangmai.com/archive/drug_use_in_thailand

Munjit, S., Tongthip, A., Jaipang, P., Pummaichaiyapreuk, A., Putthawong, K., \& Ruensit, P. (2007). Community participation in the prevention and control of addictive substances in Tambon Patan, Khuntan District, Chiang Rai Province. Journal of Health Systems Research, 1(2), 138-145.

Office of Public Relations, Khon Kaen. (2013). Youth and drug. Retrieved March 4, 2013, from http://region1.prd.go.th/ewt_news.php?nid=913\&filename=index

Office of Thai Muslim Press. (n. d.). Drugs: Forbidden in Islam. Retrieved June 24, 2012, from http://thaimuslim.com/view.php?c=6\&id=12194

Office of the Narcotics Control Board. (2013). Statistic of drug addiction in Thailand. Bangkok: Office of the Narcotics Control Board.

Patanapongsa, N. (2004). Participation: Basic principles, techniques and case studies. Chiang Mai: Chiang Mai University.

Prayatsap, P. (2011). Islam and drug. Retrieved June 24, 2012, from http://www.islammore.com/main/content.php?page=sub\&category $=4 \& \mathrm{id}=2963$

Songkhla Tanyarak Hospital. (2011). Drugs patients statistics in Songkhla. Retrieved January 14, 2012, from http://www.sdtc.go.th/paper/138

Thepsitha, S. (1998). Social control. Bangkok: The National Council on Social Welfare of Thailand.

\section{Notes}

Note 1. Maghrib (sunset): Just after the sun goes down, Muslims remember God again as the day begins to come to a close.

Note 2. Isha (evening): Before retiring for the night, Muslims again take time to remember God's presence, guidance, mercy, and forgiveness.

\section{Copyrights}

Copyright for this article is retained by the author(s), with first publication rights granted to the journal.

This is an open-access article distributed under the terms and conditions of the Creative Commons Attribution license (http://creativecommons.org/licenses/by/3.0/). 